\title{
Meiofauna of an experimental soft bottom ecosystem - effects of macrofauna and cadmium exposure
}

\author{
Brita Sundelin ${ }^{1,2}$, Ragnar Elmgren ${ }^{1,3}$ \\ ${ }^{1}$ Department of Zoology, Stockholm University, S-106 91 Stockholm, Sweden \\ ${ }^{2}$ Swedish Environmental Protection Agency, Aquatic Toxicology Section, S-611 82 Nyköping, Sweden* \\ ${ }^{3}$ Department of Systems Ecology, Section Marine Ecology, Stockholm, University, S-106 91 Stockholm, Sweden
}

\begin{abstract}
The effects of macrofauna (the amphipod Pontoporeia affinis) and of exposure to cadmium at 0 (control) and ca 5, 50 and $150 \mu \mathrm{g} \mathrm{l}^{-1}$ on a meiofauna population were studied in small, flow-through laboratory microcosms. Meiofauna was derived from a soft sediment benthos community, typical below the thermocline in the northern Baltic proper (salinity 6 to $8 \%$ ). In a first experiment ( $265 \mathrm{~d}$ ) subadult amphipods were added, while in a second experiment $(460 \mathrm{~d})$ both juveniles and subadults were included. After $265 \mathrm{~d}$ at natural field amphipod densities total meiofauna abundance was lower than in control experiments without amphipods. This was due mostly to lower nematode abundance, but also to fewer ostracods. In contrast, non-nematode meiofauna, in particular Turbellaria and harpacticoids, increased in the presence of amphipods. Effects of cadmium exposure on the meiofauna could thus be due either to direct toxicity, or to changes in macrofaunal abundance or activity caused by cadmium. Sediment cadmium concentration was a highly significant function of cadmium concentration in the input water. Dose-response relationships with sediment cadmium concentration as the independent variable were significantly negative in the presence of amphipods at $105 \mathrm{~d}$ for the abundance of nonnematode meiofauna and Turbellaria and for the biomass of non-nematode meiofauna and of total meiofauna, and at $265 \mathrm{~d}$ for ostracod abundance, harpacticoid abundance, total meiofauna biomass and biomass of non-nematode meiofauna. At $265 \mathrm{~d}$ in the absence of amphipods, a significant negative dose-response relationship was found for nematode abundance and a positive relationship for turbellarian abundance. Significant negative dose-response relationships were also obtained in the second experiment (460 d, with amphipods) for total meiofauna abundance and biomass, non-nematode biomass, nematode abundance, ostracod abundance and turbellarian abundance. Overall, ostracods were found particularly sensitive to cadmium exposure, while Turbellaria and monothalamous Foraminifera sometimes increased in cadmium-dosed microcosms, presumably due to reduced competition or predation. The microcosm system tested was found suitable for long-term experiments, and could maintain a near-natural density of meiofauna and $P$. affinis for over 1 yr. Such long-term experiments demonstrated effects of cadmium even at a concentration as low as $6 \mu \mathrm{g} \mathrm{l}^{-1}$, in the presence of sediment.
\end{abstract}

\section{INTRODUCTION}

Benthic meiofauna, i.e. Metazoa and Foraminifera small enough to pass a 0.5 or $1 \mathrm{~mm}$ sieve, are important in the energy flow of marine benthic ecosystems (Gerlach 1971). In the northern Baltic proper, meiofauna contributes about one third of the summed combined production of the benthic meio- and macrofauna (Ankar \& Elmgren 1976). Further north, in the Bothnian Bay, where primary productivity is much lower, the

\footnotetext{
- Address for correspondence
}

biomass of the meiofauna even exceeds that of the macrofauna (Elmgren et al. 1984). More effective utilization of a sparse and finely particulate food source by the meiofauna and lessened interference and predation from the macrofauna have been suggested as possible explanations for the greater importance of meiofauna in the food-limited benthic environment of the northernmost Baltic (Elmgren 1978).

The deposit-feeding amphipod Pontoporeia affinis Lindström [syn. Monoporeia affinis (Lindström), see Bousfield 1989] is the numerical dominant in the macrobenthos of the Baltic Sea. Gut analysis has shown 
that Pontoporeia eats nematodes (Elmgren 1976), and experiments have proven that it is a quantitatively important predator on newly settled, meiofauna-sized spat of the Baltic tellinid bivalve Macoma balthica (L.) (Elmgren et al. 1986). When evaluating a new microcosm system for ecotoxicological studies of the benthic ecosystem of the Baltic Sea (Sundelin 1983), we therefore included treatments without amphipods, to test whether effects of toxicant exposure on the meiofaunal community were due to direct toxicity, or to indirect effects, brought about by changed amphipod survival or activity.

When trying to predict the effects of environmental pollutants on ecosystems there are many factors to weigh before choosing a test method. Laboratory experiments with single species are inexpensive, but inadequate for predictions of effects in natural ecosystems (Cairns 1986). Large microcosms ('mesocosms') presumably reflect the natural situation better, but are difficult to standardize and their generally expensive designs often do not allow sufficient replication. Adequate replicability, discussed by Abbot (1966), Crow \& Taub (1979) and Giesy \& Allred (1985), can often be obtained more easily by using small, inexpensive microcosms, which yet retain much of the complexity of real nature. In order to determine effects on populations, it is valuable to run the experiments over at least one generation. Using meiofauna, whose comparatively short life cycles allow shorter experiments, it is possible to reduce the size of the microcosm but still have a sufficient number of individuals, of an assortment of trophic groups and species (Pilson \& Nixon 1980).

The Baltic Sea is surrounded by industrialized countries, with prominent mining and metalworking industries (Bruneau 1980). A single major Swedish polluter, the Rönnskär metal works on the coast of the Bothnian Bay (northernmost Baltic Sea), has for many years released in excess of 20 tons of cadmium per year to air (Svedberg 1987) and water (Lundbergh 1988), in combination with large amounts of lead, copper, mercury, arsenic and zinc. Cadmium concentrations of $24 \mu \mathrm{g} \mathrm{g}^{-1}$ dry weight of sediment have been recorded off the Rönnskär metal works, and even higher values have been found elsewhere in the Baltic coastal zone (references in Sundelin 1983). Studies from the central Baltic proper indicate that sediment concentrations of cadmium have increased about 7 times above preindustrial levels (Erlenkeuser et al. 1974). Considering its highly toxic nature, cadmium is thus a substance of concern in the Baltic environment.

The purpose of the study reported here was: (1) To evaluate whether the interactions between macrofauna and meiofauna were changed by exposure to cadmium, and whether the effects of cadmium exposure on the meiofauna differed in the presence of macrofauna. (2) To study long-term effects of cadmium in low concentrations on the soft-bottom meiofaunal community in the presence of the amphipod Pontoporeia affinis. Effects on $P$. affinis have already been described by Sundelin (1983). (3) To evaluate the suitability of a simple microcosm, representing a Baltic soft-bottom ecosystem, for studying the effect of pollutants.

\section{MATERIALS AND METHODS}

Microcosm system. The microcosms used were 21 Erlenmeyer flasks (Fig. 1), containing a $3 \mathrm{~cm}$ layer of natural sediment (sediment area $227 \mathrm{~cm}^{2}$ ). Seawater from $40 \mathrm{~m}$ depth entered the microcosms at a rate of $2.2 \mathrm{I} \mathrm{h}^{-1}$. The $\mathrm{pH}$ was 7.3 to 7.7 , salinity was 6.8 to $7.3 \%$, and the temperature ranged from 2 to $6^{\circ} \mathrm{C}$ over the year. Further details are given in Sundelin (1983).

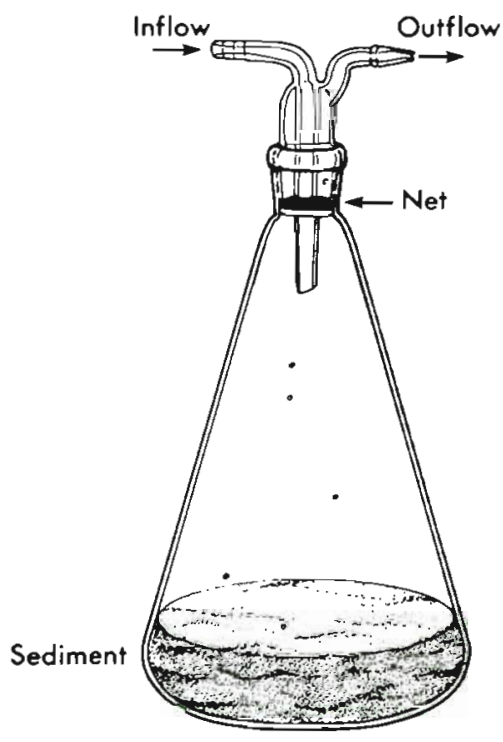

Fig. 1. The microcosm. To prevent surface contact and escape of amphipods the outlet was covered with a $0.25 \mathrm{~mm}$ mesh net. From Sundelin (1983)

Test organisms and sediment. Sediment, including populations of meio- and macrofauna, was collected with an Ockelmann (1964) dredge (mesh size $0.45 \mathrm{~mm}$ ) at a depth of $40 \mathrm{~m}$ in Hallsfjärden, northern Baltic proper, and was sieved through 1.0 and $0.5 \mathrm{~mm}$ mesh. Of the macrofauna (1 $\mathrm{mm}$ fraction) only Pontoporeia affinis was used. Macrofauna juveniles, in particular the predatory polychaete Harmothoe sarsi (Kinberg), were removed from the $0.5 \mathrm{~mm}$ fraction under a stereomicroscope. The remaining meiofauna in the $0.5 \mathrm{~mm}$ fraction was returned to the homogenized sediment before it was transferred to the microcosms in aliquots. Sediment samples were preserved in $4 \%$ 
formaldehyde buffered with hexamine, with Rose Bengal added as a stain.

Experimental design. Two experiments were started simultaneously on 26 October 1977. Experimental details are given in Table 1 . Expt 1 included subadult Pontoporeia affinis and the natural meiofauna of northern Baltic proper soft bottoms in the 25 to $50 \mathrm{~m}$ depth range. Sampling was performed after 105 d (8 February) and after $265 \mathrm{~d}$ (18 July). Cadmium was added as $\mathrm{CdCl}_{2}$, as described in Sundelin (1983). Four cadmium levels were tested, in the following referred to as control, low, medium and high, corresponding to about 0 , 5,50 and $150 \mu \mathrm{g} \mathrm{Cd} \mathrm{l}^{-1}$, respectively. The sampling at $265 \mathrm{~d}$ included similarly dosed microcosms without amphipods, in order to test for direct effects of cadmium on the meiofauna in the absence of amphipods. Expt 2, which did not use the highest cadmium concentration, included both subadult (about $1.5 \mathrm{yr}$ old) and juvenile (about $0.5 \mathrm{yr}$ old) amphipods and the natural meiofauna, and ran for 460 d until 29 January 1979.
A.-G. Engvall at the Department of Geology, Stockholm University. Homogenized samples were digested in $5 \mathrm{M} \mathrm{HNO}_{3}$ at $80^{\circ} \mathrm{C}$ for $1 \mathrm{~h}$. The sample filtrate was stored in glass bottles before analysis. Cadmium concentrations in the outgoing aquarium water were determined from pooled weekly $10 \mathrm{ml}$ samples. Analyses were carried out by U. Teder at AB Energiteknik, Studsvik. The acidified water samples were filtered through $0.45 \mu \mathrm{m}$ Millipore filters. Samples from medium and high cadmium treatments were analysed by flame AAS (Perkin Elmer 403). Control samples and low cadmium treatments were analysed by AAS with graphite furnace HGA 74. The organic content of the sediment was determined by loss on ignition. For details see Sundelin (1983).

Meiofauna analyses. The meiofauna in each microcosm was sorted with the techniques of Elmgren (1973). Individuals were determined to major taxon (Foraminifera, Turbellaria, kinorhynchs, nematodes, oligochaetes and harpacticoids) or species (ostracods,

Table 1. Experimental design and sampling schedule. Survival of Pontoporeia affinis and cadmium concentrations ( \pm SD) in the sediment on the 3 sampling occasions. $\mathrm{J}=$ juveniles; $\mathrm{C}=$ controls; $\mathrm{L}, \mathrm{M}, \mathrm{H}=$ low, medium and high cadmium treatments,

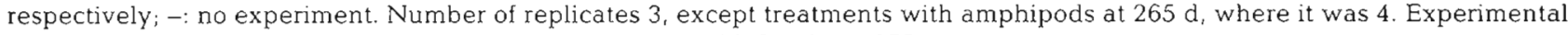
start 26 October 1977

\begin{tabular}{|c|c|c|c|c|c|c|c|}
\hline \multirow[t]{2}{*}{ Treatment } & \multirow{2}{*}{$\begin{array}{l}\text { Amphipods, } \\
\text { inital no. }\end{array}$} & \multicolumn{2}{|c|}{$105 \mathrm{~d}$} & \multicolumn{2}{|c|}{$265 d$} & \multicolumn{2}{|c|}{$460 d$} \\
\hline & & $\begin{array}{c}\mathrm{Cd} \\
\left(\mu \mathrm{g} \mathrm{g}^{-1}\right)\end{array}$ & $\begin{array}{l}\text { Amphipod } \\
\text { females } \\
\text { remaining }\end{array}$ & $\frac{C d}{\left(\mu g g^{-1}\right)}$ & $\begin{array}{l}\text { Amphipod } \\
\text { juveniles } \\
\text { remaining }\end{array}$ & $\begin{array}{c}\mathrm{Cd} \\
\left(\mu \mathrm{g} \mathrm{g}^{-1}\right)\end{array}$ & $\begin{array}{l}\text { Amphipods } \\
\text { remaining }\end{array}$ \\
\hline \multicolumn{8}{|l|}{ Expt 1: } \\
\hline $\mathrm{C}$ & $209 \%+20 \delta 0$ & $1 \pm 0.2$ & $15 \pm 1$ & $1 \pm 0.2$ & $86 \pm 20$ & - & - \\
\hline $\mathrm{L}$ & $2099+2030$ & $2 \pm 0.4$ & $12 \pm 6$ & $4 \pm 1$ & $107 \pm 23$ & - & - \\
\hline$M$ & $2099+2038$ & $9 \pm 1$ & $12 \pm 4$ & $14 \pm 1$ & $18 \pm 13$ & - & - \\
\hline $\mathrm{H}$ & $2099+200 \AA$ & $19 \pm 4$ & $2 \pm 2$ & $32 \pm 2$ & 0 & - & - \\
\hline $\mathrm{C}$ & 0 & - & - & $1 \pm 0.2$ & - & - & - \\
\hline $\mathrm{L}$ & 0 & - & - & $4 \pm 1$ & - & - & - \\
\hline$M$ & 0 & - & - & $8 \pm 4$ & - & - & - \\
\hline $\mathrm{H}$ & 0 & - & - & $26 \pm 5$ & - & - & - \\
\hline \multicolumn{8}{|l|}{ Expt 2: } \\
\hline C & $13 q 9+13 \delta \delta+52 \mathrm{~J}$ & - & - & - & - & $1 \pm 0.05$ & $\begin{array}{l}6 \pm 199 \\
15 \pm 1 \mathrm{~J}\end{array}$ \\
\hline $\mathrm{L}$ & $1399+13 \delta^{\circ}+52 \mathrm{~J}$ & - & - & - & - & $5 \pm 0.6$ & $4 \pm 199$ \\
\hline$M$ & $13 q q+13 \delta^{\prime} \delta+52 \mathrm{~J}$ & - & - & - & - & $26 \pm 3$ & $5 \pm 199$ \\
\hline
\end{tabular}

One microcosm with azoic (deep frozen) sediment was used to study immigration of meiofauna and larvae of macrofauna with the incoming water over the first 8 mo of the experiment. Another microcosm, originally without sediment, was used to measure sediment input to the microcosms over the first experimental year.

Chemical analyses. On each sampling occasion cadmium concentrations (dry weight basis) in sediment samples were determined by atomic absorption spectroscopy (AAS) (Varian AA6 oxygen-acetylene) by Dr polychaetes and bivalves). The sediment from each microcosm was first split in two, using a Humphreytype sample splitter (Dybern et al. 1976, p. 62), to give one subsample for chemical analyses and one for meiofauna analysis. The latter was passed through a 500 um sieve and then subsampled further by decantation and sample splitting (Elmgren 1973), giving a light (decantate) and a heavy residue. Of the original sample the following were examined: $500 \mu \mathrm{m}$ fraction, $1 / 2$. Heavy fraction: $200 \mu \mathrm{m}, 1 / 2 ; 100 \mu \mathrm{m}, 1 / 2$. Light frac- 
tion: $200 \mu \mathrm{m}, 1 / 16 ; 100 \mu \mathrm{m}, 1 / 128 ; 40 \mu \mathrm{m}, 2 / 1024$. The heavy $40 \mu \mathrm{m}$ fraction contained very few animals and was discarded. The light $40 \mu \mathrm{m}$ fraction was treated by ultrasound (Thiel et al. 1975) for $25 \mathrm{~s}$ to facilitate sorting. Two subsamples each from the 9 initial samples were analysed, to check that unbiased subsamples of the meiofauna were obtained. Dry weight biomasses of meiofauna groups were estimated using sieve-mesh specific conversion factors from Widbom (1984). Since such conversion factors vary, and were not tested here, biomass estimates are presented only for abundant groupings, i.e. nematodes, meiofauna other than nematodes (= non-nematode meiofauna), and total meiofauna.

In the medium and high cadmium treatments at 265 d, a single, fairly large polychaete Harmothoe sarsi but no amphipods were found in 2 out of 4 replicates with amphipods initially added. Single individuals of $H$. sarsi had probably been missed when small polychaetes were initially removed. These replicates were excluded when analysing treatment effects on Pontoporeia affinis (Sundelin 1983), but are here included in the analysis of effects on meiofauna, since amphipods were present initially, and since $H$. sarsi also eats meiofauna (Sarvala 1971).

Effects in individual treatments over time, and over treatments on a single sampling occasion, were compared statistically using either the Kruskal-Wallis analysis of variance by ranks ( $\mathrm{KW}, 2$-tailed) or the Mann-Whitney $U$-test (MWU, 2-tailed) (both Daniel 1978). The conventional significance level of $p<0.05$ was applied, except in a few cases, where $p<0.1$ was accepted as significant when this, due to the restricted number of replicates available, was the best possible evidence (BPE). For the latter type of data, only significances supported by similar trends or significances in related treatments have been given full weight. Dose-effect relationships were tested for significance with the Spearman rank correlation (Lehmann 1975). Treatment effects after $265 \mathrm{~d}$, when microcosms without macrofauna were included in the experimental design, were analyzed by analysis of variance, to test for interaction effects. The data were then $\log _{10^{-}}$or $\log _{10}(x+1)$-transformed, to stabilize variances.

\section{RESULTS}

\section{Abiotic factors}

Cadmium concentrations in the integrated effluent water samples are given in Table 2 , resulting cadmium concentrations in the sediment in Table 1. During the first $105 \mathrm{~d}$ water concentrations were lower than desired in the medium and high cadmium treatments, but modifications in the dosing method resulted in satisfactory agreement during the rest of the experiment. After $265 \mathrm{~d}$, the cadmium concentration of the sediment was significantly influenced by water concentration of cadmium (2-way analysis of variance, $p<0.0001)$ and the presence of amphipods $(p<0.05)$, with no significant interaction $(p>0.94)$. The sediment of cadmium-dosed microcosms took up 10 to $40 \%$ more cadmium when amphipods were present, as discussed by Sundelin (1983). The organic content of the sediment was $12 \%$ at the start of the experiment, and did not differ significantly between times and treatments (detailed data in Sundelin 1983). The originally empty microcosm flask accumulated a $3 \mathrm{~mm}$ layer of sediment in a year, indicating limited sediment input with the incoming water.

\section{Meiofauna analyses}

The distribution of meiofauna in the initial samples from 26 October was fairly homogeneous. The 2 subsamples from each sample were very similar (average subsample coefficient of variation $7 \%$, range 3 to $12 \%$, $\mathrm{n}=9$ ). The total Day 0 abundance estimated from the initial samples was $2.3(\mathrm{SD}=0.3) \times 10^{6} \mathrm{ind}^{-2}$ (Fig. 2).

Table 2. Cadmium concentration in the microcosm effluent water. Measured on weekly samples, pooled for the interval between samplings. $\mathrm{n}$ : number of pooled, replicate samples analysed. -: no experiment

\begin{tabular}{|c|c|c|c|c|c|c|}
\hline \multirow[t]{4}{*}{ Treatment } & \multirow{4}{*}{$\begin{array}{c}\text { Nominal } \\
\text { cadmium } \\
\text { conc. } \\
\left(\mu \mathrm{g} I^{-1}\right)\end{array}$} & \multicolumn{5}{|c|}{ Assayed cadmium concentration $\left(\mu \mathrm{gl}^{-1}\right)$} \\
\hline & & \multirow{3}{*}{$\begin{array}{c}\text { Days } \\
1-105\end{array}$} & \multirow{3}{*}{$\begin{array}{c}\text { Days } \\
105-265\end{array}$} & \multirow{3}{*}{$\begin{array}{c}\text { Days } \\
265-460\end{array}$} & \multicolumn{2}{|c|}{ Weighted mean } \\
\hline & & & & & Days & Days \\
\hline & & & & & $1-265$ & $1-460$ \\
\hline Control & 0 & $<0.2$ & $<0.2$ & $<0.2$ & $<0.2$ & $<0.2$ \\
\hline Low & 5 & $6 \pm 2$ & $6 \pm 1$ & $6 \pm 1$ & 6 & 6 \\
\hline Medium & 50 & $31 \pm 4$ & $47 \pm 3$ & $54 \pm 4$ & 41 & 46 \\
\hline High & 150 & $100 \pm 26$ & $144 \pm 2$ & - & 125 & - \\
\hline $\mathrm{n}$ & & 3 & 4 & 3 & & \\
\hline
\end{tabular}


Fig. 2. Abundance of meiofauna in the experiments. Exposure levels: $\mathrm{C}=$ control, $\mathrm{L}=$ low, $\mathrm{M}=$ medium, $\mathrm{H}=$ high $\mathrm{Cd}$ concentration. Expt 1 at left, Expt 2 at right. $\mathrm{N}=3$, except $\mathrm{N}=4$ for treatments with amphipods at $265 \mathrm{~d}$, and $\mathrm{N}=9$ for start controls (Day 0). (A) Nematodes; (B) Turbellaria and Foraminifera; (C) Ostracoda, Harpacticoida and other groups; (D) juvenile Macoma balthica; and (E) ostracod species

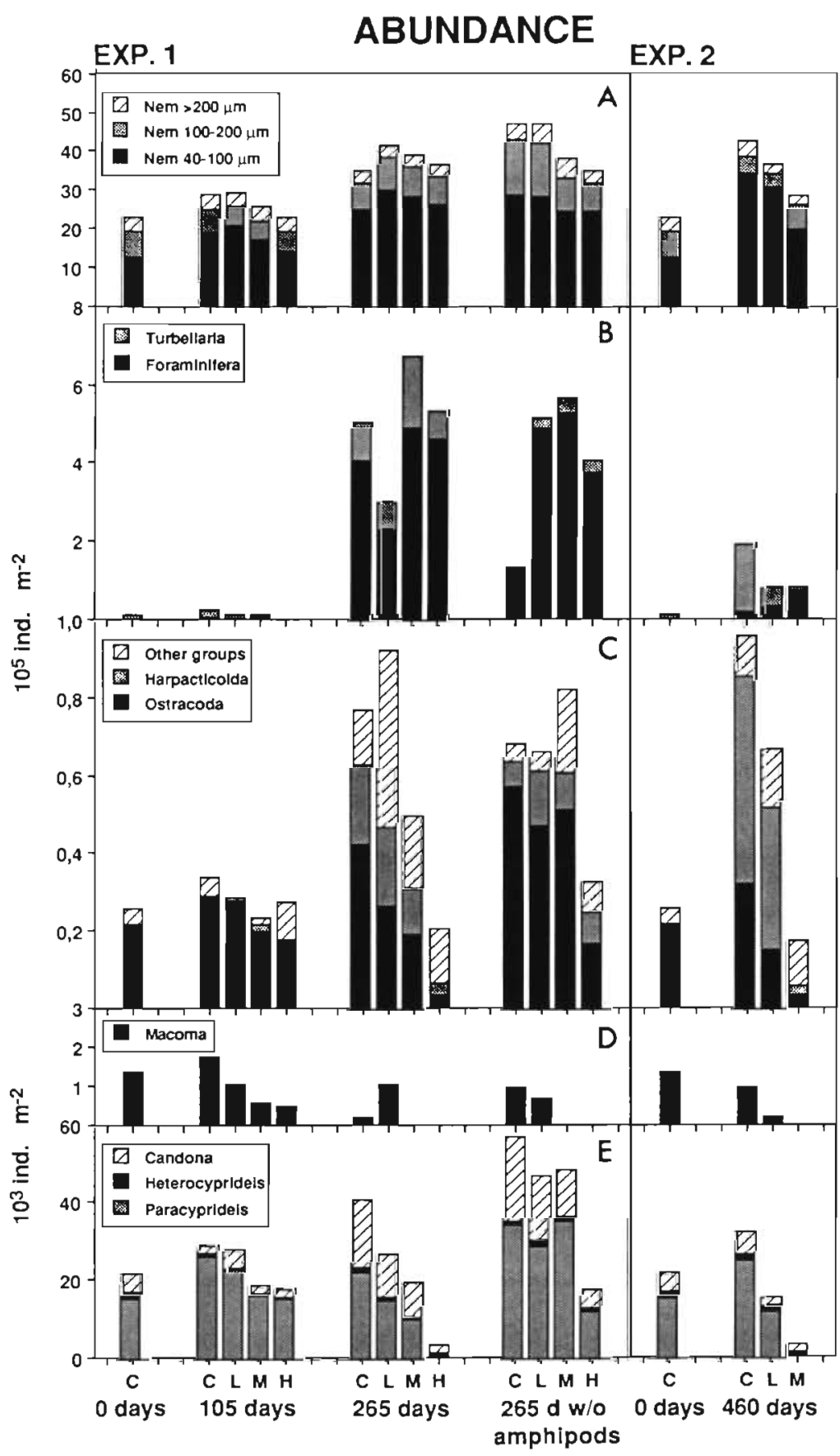

Analyses of the azoic sediment after 8 mo revealed only a few meiofauna individuals $\left(6 \times 10^{4}\right.$ nematodes, $10^{3}$ turbellaria and $10^{3}$ harpacticoids $\mathrm{m}^{-2}$ ), indicating that abundance changes within the microcosms were not greatly influenced by immigration with the water input.

\section{Control microcosms with amphipods}

In Expt 1, with adult amphipods only, the total number of meiofauna organisms changed significantly with time ( $\mathrm{KW}, \mathrm{p}=0.014$ ), due clearly to an increase from Day 105 to Day 265. This increase was mainly due to an increase in the abundance of nematodes (Fig. 2A) $(K W, p=0.014)$, especially small nematodes $(<100 \mu \mathrm{m}$; Fig. 2A; $\mathrm{KW}, \mathrm{p}=0.014)$. The estimated nematode biomass also changed significantly during the experiment ( $K W, p=0.039$ ), but the increase was less marked (Fig. 3). Groups other than nematodes (non-nematodes) (see Fig. 2B, C) also increased in abundance during the experiment ( $K W, p=0.014$ ), but non-nematode biomass (Fig. 3) did not change significantly ( $K W, p=0.34$ ). 


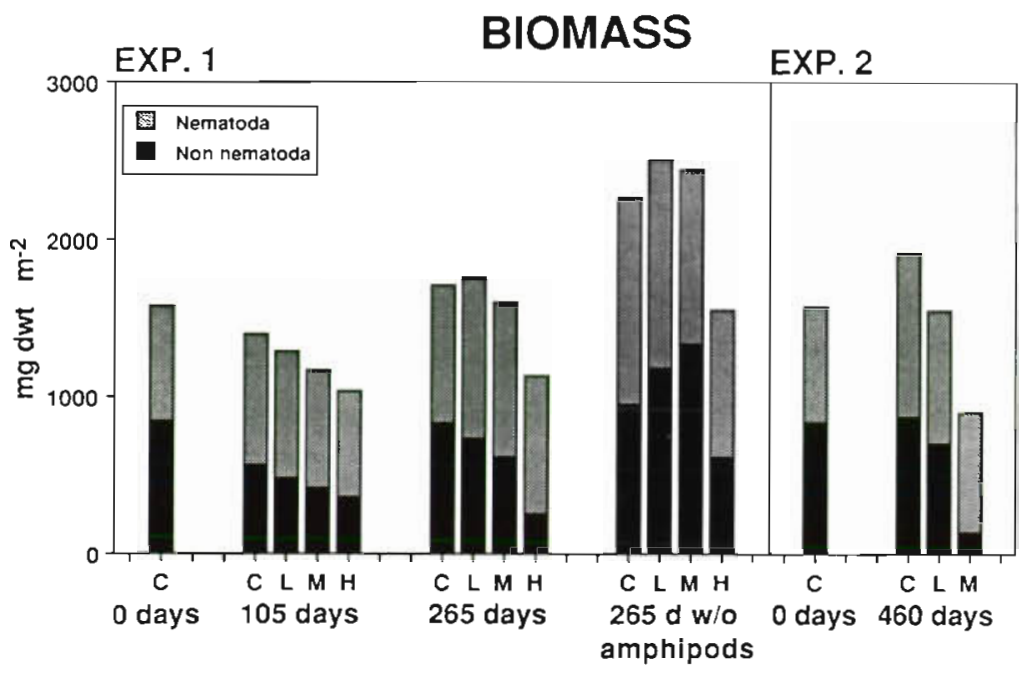

Fig. 3. Biomass of nematodes and of meiofauna groups other than nematodes in the experiments. Exposure levels: $\mathrm{C}=$ control, $\mathrm{L}=$ low, $\mathrm{M}=$ medium, $\mathrm{H}=$ high cadmium concentration. Expt 1 at left, Expt 2 at right. $N=3$, except $\mathrm{N}=4$ for treatments with amphipods at $265 \mathrm{~d}$, and $N=9$ for start controls (Day 0 )

The total abundance of ostracods (Fig. 2C, E) did not change significantly during Expt 1 ( $\mathrm{KW}, \mathrm{p}=0.26)$. Three ostracod species were recorded in the microcosms: Paracyprideis fennica (Hirschmann), Heterocyprideis sorbyana (Jones) and Candona neglecta Sars. The most abundant species was P. fennica (Fig. 2E), just as in the field (Ankar \& Elmgren 1976). Its abundance fluctuated relatively little during the experiment, while $C$. neglecta, the second most abundant ostracod in the microcosms, showed a 3 -fold increase at $265 \mathrm{~d}$ (MWU, p < 0.01) (Fig. 2E). Small C. neglecta $(<200$, $>100 \mu \mathrm{m}$ ) dominated the increase, indicating reproduction. No harpacticoid was found at the start of the experiment, and the increase during the experiment was highly significant (Fig. 2C; KW, $p=0.009$ ). Foraminifera increased 18-fold over time (Fig. 2B; KW. $\mathrm{p}=0.043$ ). Meiofaunal Macoma balthica changed significantly during Expt 1 [KW, p = 0.04; apparently due to a decrease between 105 and $265 \mathrm{~d}$ (Fig. 2D)].

In Expt 2, with both juvenile and adult amphipods, an abundance increase was found by $460 \mathrm{~d}$ for nematodes (Fig. 2A) and a very great increase for non-nematode meiofauna (Fig. 2B, C) (MWU, both $p<0.01$ ). Nematode biomass (Fig. 3) had also increased (MWU, $p<0.01$ ). Large abundance increases were noted for Turbellaria, harpacticoids (from 0 to $54 \times 10^{3}$ ind. $\mathrm{m}^{-2}$ ) and (mostly small) ostracods (Fig. 2B, C; all $p<0.01$ ).

\section{Control microcosms without amphipods}

The control microcosms without amphipods (Expt 1) also showed, at $265 \mathrm{~d}$, large increases in abundance of most meiofauna groups (from $0 \mathrm{~d}$ : nematodes, nonnematode meiofauna, Foraminifera, harpacticoids and ostracods; MWU, all $p<0.01$ ) and in the biomass of nematodes (from $0 \mathrm{~d}$ : $\mathrm{MWU}_{i} \mathrm{p}<0.01$ ), but differed clearly in other respects from those with amphipods
(Figs. 2A, B, C \& 3). Total meiofauna abundance (Fig. 2A, B, C), abundance of meiofaunal Macoma balthica (Fig. 2D), and abundance and biomass of nematodes (Figs. 2A \& 3) were significantly (MWU, all $\mathrm{p}<0.1$, $\mathrm{BPE})$ higher than in the presence of amphipods. The abundances of non-nematode meiofauna, Turbellaria and harpacticoids, on the other hand, were all significantly (MWU, $p<0.1$, BPE) lower in the absence of amphipods (Fig. 2B, C). Turbellaria had even declined from Day 0 (MWU, $\mathrm{p}<0.01$ ).

\section{Cadmium-treated microcosms with amphipods}

In Expt 1, the abundance increased significantly for total meiofauna (KW, p = 0.014) and nematodes (KW, $\mathrm{p}=0.016$ ), in the low cadmium concentration, just as in the controls, (see Fig. $2 \mathrm{~A}$ to $\mathrm{C}$ ), while non-nematode meiofauna showed borderline significance $(\mathrm{KW}, \mathrm{p}=$ 0.07 ) and biomass remained unchanged ( $\mathrm{KW}, \mathrm{p}>0.05$ for total meiofauna, nematodes and non-nematodes). In the intermediate and high concentrations of cadmium the abundance increases were not significant for total meiofauna, nematodes $(\mathrm{KW}$, both $\mathrm{p}>0.05)$ and nonnematode meiofauna ( $\mathrm{KW}$, medium: $\mathrm{p}>0.05$ ) except for non-nematode meiofauna in the high cadmium treatment ( $\mathrm{KW}, \mathrm{p}=0.045$; Fig. $2 \mathrm{~A}$ to $\mathrm{C}$ ), while biomass did not change significantly for nematodes ( $\mathrm{KW}$, $p>0.05$ ), but decreased for non-nematode meiofauna (KW, medium: $p=0.014$ and high: $p=0.021$; Fig. 3).

Among non-nematode meiofauna, Foraminifera (KW, low: $p=0.05$, medium: $p=0.03$ and high: $p=$ 0.04 ) and harpacticoids (KW, low: $p=0.0042$, medium: $p=0.09$, high: $p=0.0042$ ) increased in abundance in all cadmium treatments, while a decrease was indicated for ostracods in the high cadmium treatment (KW, borderline significance $p=0.057$; Fig. $2 \mathrm{C}, \mathrm{E}$ ). The ostracod Heterocyprideis sorbyana decreased in all 
cadmium treatments (KW, low: $\mathrm{p}=0.018$, medium: $\mathrm{p}=$ 0.014 ; Fig. 2E), due to a decrease in large individuals and a total absence of small ones $(>100,<200 \mu \mathrm{m})$. At $265 \mathrm{~d}$ ostracod abundance in the high cadmium treatment was only $15 \%$ of the control value. Meiofaunal Macoma balthica were likewise reduced in the medium and high cadmium treatments ( $\mathrm{KW}, \mathrm{p}=0.034$ and 0.048 respectively; Fig. 2D).

When analyzing cadmium effects as a dose-response relationship, significant negative relationships with sediment cadmium concentration as the independent variable were obtained at $105 \mathrm{~d}$ for abundance of nonnematode meiofauna ( $\mathrm{p}=0.034)$ and Turbellaria $(\mathrm{p}=$ $0.048)$, and biomasses of non-nematode meiofauna $(p=0.034)$ and of total meiofauna $(p=0.038)$. Sediment cadmium concentration itself was a highly significant function of cadmium concentration in the input water $(p<0.002)$. At 265 d negative relationships were obtained for ostracod abundance ( $\mathrm{p}=0.004$ ), harpacticoid abundance $(p=0.013)$, total meiofauna biomass $(\mathrm{p}=0.019)$ and biomass of non-nematode meiofauna ( $p=0.017$ ), all as functions of cadmium concentration in the sediment. The latter was a function of cadmium concentration in the water input ( $p=0.0002)$.

In Expt 2, abundance increased to $460 \mathrm{~d}$ in both cadmium treatments for total meiofauna (MWU, both $p<0.01$ ) and nematodes (MWU, low: $p<0.02$, medium: $p<0.01$; see Fig. 2 A to $C$ ), but only in the low cadmium treatment for non-nematode meiofauna (MWU, p $<0.01$; see Fig. 2B, C). Biomass increased for nematodes in the low cadmium treatment (MWU, p < 0.01; Fig. 3), but decreased for total and non-nematode meiofauna in the medium cadmium treatment (MWU, both $\mathrm{p}<0.01$; Fig. 3). Ostracod abundance decreased in low (MWU, p < 0.05) and medium (MWU, p < 0.01) cadmium treatments, with small ostracods and Paracyprideis fennica (Fig, 2E) particularly affected. Juvenile Macoma balthica were much reduced in the low cadmium treatment and wiped out in the medium (MWU, both $\mathrm{p}<0.01$; Fig. 2D).

When the results of Expt 2 were analyzed as a doseresponse relationship, significant negative relationships were obtained between cadmium concentration in the sediment and total meiofauna abundance ( $\mathrm{p}=$ $0.024)$ and biomass $(p=0.011)$, non-nematode biomass $(p=0.017)$, nematode abundance $(p=0.024)$, ostracod abundance $(p=0.016)$ and turbellarian abundance $(\mathrm{p}=0.017)$. The cadmium concentration in the sediment was a function of cadmium concentration in the water input ( $\mathrm{p}=0.009)$.

For the lowest cadmium concentrations, we also tested differences against the controls, to try to establish the lowest observed effect concentration in the experiment. Compared to the control, biomass was lower for total and non-nematode meiofauna and for nematodes in both low and medium cadmium treatments, as was the abundance of ostracods and Turbellaria (MWU, all $\mathrm{p}<0.1, \mathrm{BPE}$ ). The abundance of total and non-nematode meiofauna, as well as nematodes, was significantly lower in the medium cadmium treatment only (MWU, $\mathrm{p}<0.1, \mathrm{BPE}$ ).

\section{Cadmium-treated microcosms without amphipods}

All treatments showed significant increases (MWU, $p<0.01$ ) over initial values at $265 \mathrm{~d}$ for nematode abundance (Fig. 2A) and biomass (Fig. 3), and for abundances of total meiofauna, non-nematode meiofauna, Foraminifera and harpacticoids (Fig. 2A to C). Biomasses of total meiofauna and of non-nematode meiofauna had increased (MWU, all $\mathrm{p}<0.01$ ), except for non-nematode biomass in the high cadmium treatment (MWU, $\mathrm{p}>0.05$ ). Ostracods had increased in the low and medium cadmium treatments (MWU, p < 0.01 ), but decreased very sharply in the high (MWU, $\mathrm{p}<0.05$ ). Meiofaunal Macoma balthica disappeared in the medium and high cadmium treatments (MWU, both $p<0.01$; Fig. 2D)

Comparing like cadmium treatments with and without amphipods at 265 d revealed no significant differences in the low cadmium dose, while in the medium cadmium dose Turbellaria were less common (MWU, $\mathrm{p}<0.1, \mathrm{BPE}$ ) and ostracods more common (MWU, $\mathrm{p}<0.1, \mathrm{BPE}$ ) in the absence of amphipods, and the same was true for ostracods in the high cadmium dose (MWU, $\mathrm{p}<0.1, \mathrm{BPE}$ ).

A negative dose-response relationship was found for nematode abundance $(\mathrm{p}=0.021)$ and a positive relationship for Turbellaria abundance ( $p=0.03$ ), both as functions of sediment cadmium concentration. The latter was a function of cadmium concentration in the water input $(\mathrm{p}<0.002)$.

At $265 \mathrm{~d}$ the experimental design allowed comparisons of effects due to amphipods and to cadmium, and analysis of possible interactive effects, using 2-way analysis of variance. Such analyses for log-transformed abundance of major meiofauna groupings (total and non-nematode meiofauna, nematodes, Foraminifera, Turbellaria, harpacticoids, ostracods and kinorhynchs) showed significant effects (using $p<0.05$ as the criterion) for ostracods, which were very strongly negatively affected by both cadmium exposure $(p<0.0001)$ and amphiphods ( $p<0.0001$ ), with a nearly significant interaction term $(\mathrm{p}<0.052)$, and for Turbellaria, which were positively influenced by the presence of amphipods ( $\mathrm{p}<0.031$ ), but not affected by cadmium ( $\mathrm{p}>$ 0.2 ). The abundance of meiofaunal Macoma balthica was negatively affected by cadmium ( $p<0.0001)$ but not significantly so by amphipod presence $(p<0.22)$. 
The interaction term was, however, strongly significant ( $p<0.001$ ), making evaluation difficult. Total meiofauna biomass, and biomass of non-nematode meiofauna, were negatively affected by both cadmium (both $\mathrm{p}<0.0005$ ) and amphipods (both $\mathrm{p}<0.0005$ ), while nematode biomass was negatively affected by amphipods $(p<0.02)$, but not by cadmium ( $p>0.2$ ). There were no significant interaction effects for the tested biomass variables.

\section{DISCUSSION}

The abundance of most major meiofauna groups increased with time in the microcosms. The initial abundance was only one third of field abundance (Askö area below $30 \mathrm{~m}$; Ankar \& Elmgren 1976), and the smallest meiofauna fraction was less prevalent than in field samples, probably partly because of the coarse mesh of the Ockelmann dredge. The initial abundance of Foraminifera and Turbellaria was particularly low in comparison with later dates. Harpacticoids were not found at the start of the experiment but increased during the experiment to a level only slightly lower than in situ. Some nauplii may have been missed in the subsampling, or resting eggs may have been present in the sediment (Coull \& Dudley 1976). The increases later recorded in these groups must have been due mainly to reproduction in the microcosms, since few organisms were brought in by the water flow. The increases recorded were well within the known reproductive capacity of the groups concerned (Gerlach 1971, for harpacticoids Heip 1972).

\section{Effiect of macrofauna}

The results recorded at $265 \mathrm{~d}$, which allow comparison of microcosms with and without amphipods, show that the population of ostracods in control treatments had increased significantly less in the presence of amphipods (Fig. 2C, E), and the same was true for nematodes (Fig. 2A), while newly settled Macoma balthica even decreased (Fig. 2D). The results support our preliminary microcosm experiments, reported by Elmgren (1978), suggesting a negative relationship between Pontoporeia affinis and nematodes. These negative relationships are likely to be due at least partly to direct predation by the amphipods, since Pontoporeia is known to eat small nematodes (Elmgren 1976), and small $M$. balthica spat (Elmgren et al. 1986). The intensive bioturbation by the amphipods (Elmgren et al. 1986) may also contribute to the negative relationships. Positive or negative effects of other macrofauna species on meiofauna in sediments have been reported by e.g. Federle et al. (1983), Dye \& Lasiak (1986), Warwick et al. (1986), Dobbs \& Guckert (1988), DePatra \& Levin (1989) and Reidenauer (1989).

These results indicate that many of the effects recorded on the meiofauna populations in the cadmium dosed microcosms with amphipods may have been due not to direct toxic effects on the meiofauna, but to indirect effects resulting from the toxic action of cadmium on the amphipods, described by Sundelin (1983).

In control microcosms and low cadmium treatments without amphipods, the abundance of medium-sized nematodes $(>100,<200 \mu \mathrm{m})$ was significantly higher than for microcosms with amphipods (Fig. 2A). In the medium cadmium dose, large nematodes $(>200,<500$ $\mu \mathrm{m})$ were significantly more abundant in the absence of amphipods. There were no differences in the high cadmium dose due to the initial presence of amphipods, but then only a single amphipod survived until sampling in this treatment. That there were fewer significant differences at $265 \mathrm{~d}$ between treatments with and without amphipods added, the higher the cadmium dose, may be due both to fewer amphipods surviving in high cadmium doses, and to cadmium in some instances having similar effects as amphipod presence. The presence of a Harmothoe sarsi in 2 of the 4 microcosms with amphipods and either medium or high cadmium dose also meant fewer surviving amphipods, and may have reduced the number of significant differences between treatments with and without amphipods at higher cadmium doses. Since $H$. sarsi is known as a predator on meiofauna as well as macrofauna (Sarvala 1971) it can be expected to eat and disturb the meiofauna, but hardly to have exactly the same effect as the amphipod.

At $265 \mathrm{~d}$, analysis of variance confirmed many of the trends found when testing individual cadmium levels with and without amphipods. That others are not confirmed may be due to the stricter significance criterion $(p<0.05)$ applied, as well as the decreasing effect of amphipods at higher cadmium levels, noted above. Nevertheless, the results from $265 \mathrm{~d}$ make it clear that the response of the meiofauna community to cadmium differed in the presence of macrofauna and in its absence.

Significant effects of cadmium exposure on the meiofauna were recorded also in the absence of amphipods, namely a decrease in abundance of ostracods, nematodes and an increase in Turbellaria. Some of these changes may be due not to direct cadmium toxicity, but rather to changes in competitive and predatory relationships within the meiobenthos. Thus, it is hard to believe that cadmium would be directly beneficial to the Turbellaria that increased. The higher turbellarian abundance in microcosms with amphipods could possibly be due to the death of adult amphipods after 
spawning providing potential turbellarian scavengers with extra food. The main food of Turbellaria is thought to be oligochaetes, nematodes and diatoms (McIntyre 1969), but there is little evidence that they prey on ostracods (Watzin 1985). Since the marine nematodes tested have been found quite resistant to cadmium (Vranken et al. 1985), the nematodes may have declined at least partly as the result of an increase in predatory/scavenging Turbellaria, rather than as a direct toxic effect.

In the following we summarize effects on the meiofauna community in the presence of macrofauna, without attempting to differentiate between direct toxic effects and indirect effects due to changed biotic interactions.

\section{Effect of cadmium exposure}

All 3 species of ostracod accurring in the microcosms seem to be sensitive to cadmium. The relative abundance of the major ostracod species was fairly constant (Fig. 2E). The greatest reductions in abundance was observed for small ostracods, indicating disturbed reproduction. A 2 yr life-cycle is probable for Paracyprideis fennica and Heterocyprideis sorbyana, while Candona neglecta may have a 1 yr cycle (Ankar \& Elmgren 1976). In at least 2 of the species the larger individuals at $460 \mathrm{~d}$ may thus be survivors from the start of the experiment. Results from the 'Tsesis' oil spill investigation, where ostracods were nearly eliminated (Elmgren et al. 1983), suggest that recovery of such populations may take several years.

A remarkable increase was observed for monothalamous Foraminifera, which caused the peak in abundance of Foraminifera at $265 \mathrm{~d}$ in all treatments. They seemed to be the most resistant to cadmium of all meiofauna groups investigated, emphasizing the opportunistic nature of some monothalamous Foraminifera (Lee 1974), but varied much from microcosm to microcosm, resulting in few significant differences between treatments.

\section{Sensitivity of the test system}

The biomasses of total meiofauna, nematodes and non-nematode meiofauna, and the abundances of ostracods and Turbellaria, were all negatively affected after $460 \mathrm{~d}$ at an assayed cadmium concentration of about $6 \mu \mathrm{gl}^{-1}$, as was the amphipod Pontoporeia affinis (Sundelin 1983). In acute 96-h tests some brackish water nematodes have been reported to be extremely resistant to cadmium (Vranken et al. 1985). Such conventional tests are, however, too brief to adequately reflect the toxicity of heavy metals (Best \& Morita
1983), and when the experiments were extended to $312 \mathrm{~h}$, the $\mathrm{LD}_{50}$ concentration decreased by almost $80 \%$ (Vranken et al. 1985). Since cadmium is excreted relatively slowly, long experiments may be needed to fully evaluate its toxicity. Most studies of the effect of cadmium on marine meiofauna have been acute tests on single species, and it is thus not surprising that reported effect levels (Verriopoulos \& Moraitou-Apostolopoulou 1982, Howell 1984, Vranken et al. 1985, Verriopoulos \& Dimas 1988) are generally considerably higher than those found in our long-term microcosm test.

Death is a coarse test parameter, and changing to a more sensitive effect parameter may lower the effect concentration considerably, e.g. for the nematode Panagrellus redivivus from $11.2 \mathrm{mg} \mathrm{Cd}^{-1}$ for reduced survival to $11.2 \mu \mathrm{g} \mathrm{Cd} \mathrm{\textrm {l } ^ { - 1 }}$ for reduced fecundity (Samoiloff 1980, Samoiloff et al. 1980). In population tests, D'Agostino \& Finney (1974) found cadmium to inhibit growth and development of the harpacticoid Tigriopus japonicus at $44 \mu \mathrm{g} \mathrm{Cd} \mathrm{l}^{-1}$. Brand et al. (1986) reported a $25 \%$ reduction of the population size of the same harpacticoid after $24 \mathrm{~d}$ at $2.3 \mu \mathrm{g} \mathrm{Cd}^{-1}$. For Nitocra spinipes, another harpacticoid, Bengtsson \& Bergström (1987) found a $96-\mathrm{h} \mathrm{LC}_{50}$ of 0.4 to $0.8 \mathrm{mg} \mathrm{l}^{-1}$, while fecundity was reduced at as low as 6 to $100 \mu \mathrm{g}^{-1}$.

When comparing toxicity tests many factors, such as length of exposure, salinity, temperature and the presence of sediment, as well as its organic content, have to be considered. The toxicity of cadmium decreases with increasing salinity, but tends to increase with increasing temperature (Theede et al. 1979). The availability of cadmium decreases in the presence of natural sediment (Schuytema et al. 1984).

\section{Evaluation of test system}

Translating results obtained in vitro to natural environments is a major problem in environmental regulation. There are few investigations which allow even tentative extrapolation to field conditions. Müller (1977, 1979) reported effects of heavy metals on meiofauna in benthic microcosms. Cadmium concentrations of 10 and $50 \mu \mathrm{g} \mathrm{Cd} \mathrm{l}^{-1}$ reduced the populations of ostracods and copepods, while nematodes were less affected. Despite difficulties in comparing the sensitivity of test methods, the test system described here is capable of detecting effects at $6 \mu \mathrm{g} \mathrm{Cd} \mathrm{l}^{-1}$, about as low a level of cadmium as the most sensitive test systems reported from marine waters elsewhere. A greater number of replicates for each treatment than used here is, however, recommended for increasing the sensitivity of the test system.

The microcosm system described here has also functioned well in hazard evaluation of arsenic (Blanck et 
al. 1989, Landner et al. 1989), bleached pulp mill effluents (Sundelin 1988) and 4,5,6-trichloroguaiacol (Sundelin unpubl.).

The experiments reported here illustrate the importance of long experimental duration, approaching or exceeding that of the life-cycle of important members of the studied community, in ecotoxicological hazard assessment. Only on the last sampling occasion after $460 \mathrm{~d}$ were significant results on meiofauna obtained in the lowest cadmium concentration tested. An increased frequency of abnormal eggs in Pontoporeia affinis was detected after $105 \mathrm{~d}$ at this concentration (Sundelin 1983), in another experiment after 60 d (Sundelin 1984), suggesting that this reproductive parameter may sometimes be more sensitive than population changes in detecting low, but harmful levels of pollution.

Altogether, tests using this system have demonstrated population effects at cadmium levels in the sediment (ca $5 \mu \mathrm{g} \mathrm{Cd} \mathrm{g}^{-1}$ ) considerably below those reported from several polluted localities in the Baltic Sea (24 to $140 \mu \mathrm{g} \mathrm{Cd} \mathrm{g}^{-1}$; references in Sundelin 1983), emphasizing the concern for cadmium as a marine pollutant in the Baltic Sea area.

Acknowledgements. This work was supported by grants from the National Swedish Environment Protection Board to B. Sundelin, and from the Swedish Natural Science Research Council to R. Elmgren. Olle Svanberg at SNV, Studsvik, and Bengt-Owe Jansson, Askö Laboratory, provided access to research facilities at their institutes. Ulf Larsson and Sture Hansson gave valuable help and advice. Gun Åkerman sorted meiofauna and made the final calculations. Bengt-Erik Bengtsson, Erik Bonsdorff, Catherine Hill, Emil Olafsson and Bertil Widbom gave valuable comments on the manuscript. Ulf Larsson, Emil 'Olafsson and Ann-Sofi Matthiesen helped with statistical analyses. Bibi Mayrhofer drew the figures.

\section{LITERATURE CITED}

Abbott, W (1966). Microcosm studies on estuarine waters. I. The replicability of microcosms. J. Water Pollut. Control Fed. 38: 258-270

Ankar, S., Elmgren, R. (1976). The benthic macro- and meiofauna of the Askö-Landsort area (northern Baltic proper). A stratified random sampling survey. Contrib. Askö Lab. Univ. Stockholm 11. 1-115

Bengtsson, B.-E., Bergström, B. (1987). A flow-through fecundity test with Nitocra spinipes (Harpacticoidea Crustacea) for aquatic toxicity. Ecotoxicol environ. Safety 14: 260-268

Best, J. B., Morita, M. (1983). Toxic response of planarians to various waterborne heavy metals. In: Nriagu, J. O. (ed.) Aquatic toxicology. John Wiley and Sons, New York, p. $137-154$

Blanck, H., Holmgren, K. Landner, L., Norin, H., Notini, M., Rosemarin, A., Sundelin, B. (1989). Advanced hazard assessment of arsenic in the Swedish environment. In: Landner, L. (ed.) Chemicals in the aquatic environment, advanced hazard assessment. Springer-Verlag, Berlin, p. $256-328$

Bousfield, E. L. (1989). Revised morphological relationships within the amphipod genera Pontoporeia and Gam- maracanthus and the 'glacial relict' significance of their postglacial distributions. Can. J. Fish. Aquat. Sci. 46: $1714-1,725$

Brand, G. W., Fabris, G. J., Arnott, G. H. (1986). Reduction of population growth in Tisbe holothuriae Humes (Copepoda: Harpacticoida) exposed to low cadmium concentrations. Aust. J mar. Freshwat. Res. 37: 475-479

Bruneau, L. (1980). Pollution from industries in the Baltic drainage area. Ambio 9: 145-152

Cairns, J. J. (1986). The myth of the most sensitive species. BioSci. 36: 670-672

Coull, B. C., Dudley, B. W (1976). Delayed naupliar development of meiobenthic copepods. Biol. Bull. mar. biol. Lab., Woods Hole 150: $38-46$

Crow, M. E., Taub, F. B. (1979). Designing a microscosm bioassay to detect ecosystem level effects. Int. J. environ. Stud. 13: 141-147

D'Agostino, A., Finney, C. (1974). The effect of copper and cadmium on the development of Tigniopus japonicus. In: Vermberg, F. J. (ed.) Pollution and physiology of marine organisms. Academic Press, New York, p. 445-463

Daniel, W W (1978). Applied nonparametric statistics. Houghton Mifflin Co., Boston

DePatra, K. D. Levin, L. A. (1989). Evidence of passive deposition of meiofauna into fiddler crab burrows. J. exp. mar. Biol. Ecol. 125: 173-192

Dobbs, F. C., Guckert, J. B. (1988). Calianassa trilobata (Crustacea: Thalassinidea) influences abundance of meiofauna and biomass, composition and physiological state of microbial communities within its burrow. Mar. Ecol. Prog. Ser 45: $69-79$

Dye, A. H., Lasiak, T. A. (1986). Microbenthos, meiobenthos and fiddler crabs: trophic interactions in a tropical mangrove sediment. Mar. Ecol. Prog. Ser. 32: 259-264

Dybern, B. I., Ackefors, H., Elmgren, R. (eds.) (1976). Recommendations on methods for marine biological studies in the Baltic Sea. The Baltic Marine Biologists Publ. 1: 1-98

Elmgren, R. (1973). Methods of sampling sublittoral soft bottom meiofauna. Oikos Suppl. 15: 112-120

Elmgren, R. (1976). Baltic benthos communities and the role of the meiofauna. Contrib. Askö Lab., Univ. Stockholm 14: $1-31$

Elmgren, R. (1978). Structure and dynamics of Baltic benthos communities, with special reference to the relationship between macro- and meiofauna. Kieler Meeresforsch Sonderh. 4: 1-22

Elmgren, R., Ankar, S., Marteleur, B., Ejdung, G. (1986). Adult interference with postlarvae in soft sediments: the Pontoporeia-Macoma example. Ecology 67: 827-836

Elmgren, R., Hansson, S., Larsson, U., Sundelin, B., Boenm, P D. (1983). The Tsesis oil spill; Acute and long term effects on the benthos. Mar. Biol. 73: 51-65

Elmgren, R., Rosenberg, R., Andersin, A. B., Evans, S., Kangas, P., Lassig, J., Leppäkoski, E., Varmo, R. (1984) Benthic macro- and meiofauna in the Gulf of Bothna (northern Baltic). Finn. mar. Res. 250: 3-18

Erlenkeuser, E., Suess, E., Willkomm, H. (1974). Industrialization affects heavy metal and carbon isotope concentrations in recent Baltic Sea sediments. Geochim. Cosmochim Acta 38: 823-842

Federle, T W., Livinstone, R. J., Meeter, D. A., White, D. C (1983). Modifications of estuarine sedimentary microbiota by exclusion of epibenthic predators. J. exp. mar Biol Ecol. 73: 81-94

Gerlach, S. A. (1971). On the importance of marine meiofauna for benthos communities. Oecologia (Berl.) 6: 176-190

Giesy, J. P., Allred, P. M. (1985). Replicability of aquatic 
multispecies test systems. In: Cairns, J. J. (ed.) Multispecies toxicity testing. Pergamon Press, New York, p. $187-245$

Heip, C. (1972). The reproductive potential of copepods in brackish water Mar. Biol. 12: 219-221

Howell, R. (1984). Acute toxicity of heavy metals to two species of marine nematodes. Mar. environ. Res. 11: $153-161$

Landner, L., Blanck, H., Heyman, U., Lundgren, A., Notini, M., Rosemarin, A., Sundelin, B. (1989). Community testing, microcosm and mesocosm experiments: ecotoxicological tools with high ecological realism. In: Landner, L. (ed.) Chemicals in the aquatic environment, advanced hazard assessment. Springer-Verlag, Berlin, p. 216-254

Lee, J. J. (1974). Toward understanding the niche of Foraminifera. In: Hedley, R. C. (ed.) Foraminifera 1: $207-260$

Lehmann, E. L. (1975). Nonparametrics: statistical methods based on ranks. Holden-Day Inc., San Francisco

Lundbergh, K. (1988). Utsläpp och ătgärder vid Rönnskärsverken. Vatten 44: 158-161

McIntyre, A. D. (1969). Ecology of marine meiobenthos. Biol Rev. 44: 245-290

Müller, D. (1977). Störung mariner Wattenbiocoenosen durch toxische Abwasserkomponenten. Arch. Hydrobiol. Beih. Ergebn. Limnol. 9: 151-160

Müller, D. (1979). Sublethale und lethale Schädigungen von Vertretern der Lebensgemeinschaft der Außenelbewatten durch die Schwermetalle Kupfer, Cadmium und Blei Arch. Hydrobiol./Suppl. 43: 289-346

Ockelmann, K. W. (1964). An improved detritus sledge for collecting meiobenthos. Ophelia 1.217-222

Pilson, M. E. Q., Nixon, S. W (1980). Marine microcosms in ecological research. In: Giesy, J. P. Jr (ed.) Microcosms in ecological research. DOE Symp. Ser. 52 'CONF-781101' U.S. Department of Energy (ISBN 0-87079-121-4), Sprıngfield, Virginía, p. 724-741

Reidenauer, J. A. (1989). Sand-dollar Melitta quinquiesperforata (Leske) burrow trails: sites of harpacticoid disturbance and nematode attraction. J. exp. mar. Biol. Ecol. 130 $223-235$

Samoiloff, M. R. (1980). Action of chemical and physical agents on freeliving nematodes. In: Zuckerman, B. M. (ed.) Nematodes as biological models, Vol. 2. Aging and other model systems. Academic Press, London, p. 81-98

Samoiloff, M. R., Schulz, S., Jordan, J., Denich, K., Arnolt, E. (1980). A rapid simple long-term toxicity assay for aquatic contaminants using the nematode Panagrellus redivivus. Can. J. Fish. Aquat. Sci. 37: 1167-1174

Sarvala, J. (1971). Ecology of Harmothoe sarsi Malmgren (Polychaeta, Polynoidae), in the northern Baltic area. Ann. Zool. Fennici 8: 231-309

This article was submitted to the editor
Schuytema, G. S., Nelson, P. O., Malvey, K. W., Nebeker, A. V., Krawczyk, D. F., Ratcliff, A. K., Gakstater, J. H. (1984). Toxicity of cadmium in water and sediment slurries to Daphnia magna. Environ. Toxic. Chem. 3: 293-308

Sundelin, B. (1983). Effects of cadmium on Pontoporeia affinis (Crustacea: Amphipoda) in laboratory soft-bottom microcosms. Mar Biol. 74: 203-212

Sundelin, B. (1984). Single and combined effects of lead and cadmium on Pontoporeia affinis (Crustacea, Amphipoda) in laboratory softbottom microcosms. In: Persoone, G. Jaspers, E., Claus, C. (eds.) Ecotoxicological testing for the marine environment. State Univ. Ghent and Inst. Mar Scient. Res., Bredene, Belgium, Vol. 2, p. 237-258

Sundelin, B. (1988). Effects of sulphate pulp mill effluents on soft bottom organisms - a microcosm study. Wat. Sci. Tech. $20(2)$ : 175-177

Svedberg, R. (1987). Utsläpp från metallsmältverk - omfattning, effekter, reningsmöligheter In: Arnberg, U., Nilsson, J. (eds.) Kusthav. Rapport från Svenska Naturvårdsföreningens höstkonferens 1986 (ISNB: 91-558-3521-x), Stockholm, p. 55-66

Theede, H., Scholz, N., Fischer, H. (1979). Temperature and salinity effects on the acute toxicity of cadmium to Laomedea loveni (Hydrozoa). Mar Ecol. Prog. Ser 1: 13-19

Thiel, H., Thistle, D., Wilson, G. D. (1975). Ultrasonic treatment of sediment samples for more efficient sorting of meiofauna. Limnol. Oceanogr. 20: 472-473

Verriopoulos, G., Dimas, S. (1988). Combined toxicity of copper, cadmium, zinc, lead, nickel and chrome to the copepod Tisbe holathuriae. Bull environ. Contam. Toxicol. $41 \quad 378-384$

Verriopoulos, G., Moraitou-Apostolopoulou, M. (1982). Differentiation of the sensitivity to copper and cadmium in different life stages of a copepod. Mar. Pollut. Bull. 13: $123-125$

Vranken, G., Vanderhagen, R., Heip, C. (1985). Toxicity of cadmium to free-living marine and brackish water nematodes (Monhystera microphthalma, Monhystera disjuncta, Pellioditis marina). Dis. aquat. Org. 1: 49-58

Warwick, R. M., Gee, J. M., Berge, J, A., Ambrose, W (1986). Effects of the feeding activity of the polychaete Streblosoma bairdi (Malmgren) on meiofaunal abundance and community structure. Sarsia 71: 11-16

Watzin, M. C. (1985). Interactions among temporary and permanent meiofauna: observations on the feeding and behaviour of selected taxa. Biol. Bull. mar. biol. Lab., Woods Hole 169: 397-416

Widbom, B. (1984). Determination of average individual dry weights and ash-free dry weights in different sieve fractions of marine meiofauna. Mar. Biol. 84: 101-108

Manuscript first received: January 31, 1990

Revised version accepted: December 21, 1990 